\title{
What works? Flexibility as a Work-Participation Strategy for People with Addiction and Mental- Health Problems
}

\section{Gunnar Vold Hansen*}

Faculty of Health and Social Studies

Østfold University College

Email: gunnar.v.hansen@hiof.no

${ }^{*}$ corresponding author

\section{Ragnhild Fugletveit}

Faculty of Health and Social Studies

Østfold University College

Email: ragnhild.fugletveit@hiof.no

\section{Petter A. Arvesen}

Faculty of Health and Social Studies

Østfold University College

Email: petter.a.arvesen@hiof.no

\begin{abstract}
For many years the education and training of people with addictions and mental-health problems have been a key strategy to assist people to find ordinary jobs. This strategy is largely concerned with adapting people to the requirements of the workplace. An alternative strategy can also be envisaged, where the workplace adapts to the possibilities and resources of the people (Hansen, 2009). In this article, we raise the following question: how is it possible to adapt workplaces for people with addiction and mental-health problems? Here we highlight the experiences of a workplace that focuses on adapting to employees' capabilities and resources. The data collection consists both of 12 interviews with managers and workers and of participant observation of the workplace. Our answer to our question is that this is possible because the workplace is flexible in the way that they adapt their demands to the workers' resources.
\end{abstract}

Keywords: work, addictions and mental disorders, flexibility, integration and normalization, user participation and resource orientation 


\section{Background}

In 2007, the Norwegian government presented its 'National Strategic Plan for Work and Mental Health 2007-2012' (Nasjonal strategiplan for arbeid og psykisk helse 2007-2012). This was followed in 2013 by the 'National Followup Plan for Work and Mental Health 2013-2016' (Oppfølgingsplan for arbeid og psykisk helse 2013-2016). The latter plan has aimed to increase employment of people with mental-health problems, but has also stressed the need for more knowledge about how this goal can be achieved. The plan emphasizes that a number of people mental-health problems also have problems with alcohol or drugs and that the measures outlined in the plan also apply to people with these problems. The definition of mental-health problems used in this article is taken from the Norwegian National Strategic Plan for Work and Mental Health 2007-2012, which states:

Mental-health problems (troubles or difficulties): Severity of symptoms such as various levels of anxiety, depression, and insomnia. The severity of the symptom does need not to be diagnosed (p. 7, our translation).

In this article, we present the positive experiences of an initiative primarily aimed at people with alcohol and drug problems but which also included people with mental-health problems, and we identify some of the underlying reasons why the initiative was successful in our case. Our intention is to contribute to a better understanding of how the employment for people with addiction and mental-health problems can be achieved by the presentation of a successful example. We shall start our presentation with some arguments for why work is important - especially for people with addiction and mentalhealth problems. Later, we question whether it is always the characteristics of the individuals that make their employment difficult. In order to answer this question we present 'the jobs demand-resources model', and claim that this model explains that a likely explanation is that it is characteristics of the workplace that makes it hard for this group to get a job.

\section{Work is important - also for people with addiction and mental-health problems.}

Work is a concept to which many people have an ambivalent relationship. Work is often part of the reason why people get ill and drop out of the workforce. Stress and burnout can lead to mental-health problems (Elstad \& Vabø, 2008). At the same time, it is generally agreed that adapted work can also be a means of helping people with mental-health problems to improved coping and participation in society (Ose et al., 2009). Work thus emerges both as a cause of mental-health problems and as a means of reducing mentalhealth problems.

Most people perceive mental-health problems negatively and absence from work tends to reduce one's social network and participation and can in turn worsen mental disorders such as depression and burnout (Dekkers-Sánchez et al., 2008). People outside the workforce report a poorer quality of life than people at work (Thorsen \& Claussen, 2008; Hansen \& Dybvik, 2009). For those who want work, being unemployed is thus a major problem. For employers and society, this means increased costs and reduced production. The Organisation for Economic Co-operation and Development (OECD) goes 
so far as to describe the fact that illness leads to so many cases of reduced work capacity and leaving the workforce that is a 'social and economic tragedy' (2010, p. 9).

A large proportion of those outside the workforce have a mental-health disorder and mental problems seem to be the fastest growing cause of sick leave and disability benefit. Medically certified sickness absence due to mental disorders accounted for just under 20 per cent of the total absence in Norway in the fourth quarter 2012 (Sundell, 2013) Some workers get a sick note with a mental-health diagnosis and only temporarily leave the workforce, at least in the first instance. More worrying is perhaps the trend in disability benefits. Musculoskeletal disorders are the diagnostic group with the greatest number of people on disability benefit, while mental-health diagnosis is the secondlargest group. The challenge, however, is that those who are leaving work owing to mental-health diagnosis are becoming younger and there is a deep concern that they will remain on disability benefits for much of their lives. This means that mental-health disorders might eventually be the cause of the greatest number of lost working years (Mykletun, 2009). Absence from work is therefore a problem for the society in general, but it is also a problem for the individuals, as we shall see next.

Hammer and Øverbye (2006) call work an 'identity marker'. People are described in terms of the work they do and those who do not have jobs for various reasons have to make quite an effort to justify this situation. To work to be productive in society - is generally regarded as the most basic requirement for a person to function as a true member of the social community. Reneflot and Evensen (2011) refer to Jahoda (1982), who argues that work upholds a number of important elements in human life. Participation in employment involves time structure, social contact, collective purpose and shared experiences, social identity, and regular activity. Work also provides adults with an economic basis for an independent life. Through work, an individual can demonstrate that he or she can contribute to the community. Thus work participation is an important part of most people's lives.

A number of studies (Van Dongen, 1996; Evans \& Repper, 2000) show that being outside the workforce is perceived by users of the mental-health services as a burden. Thorsen and Clausen (2008) find a clear correlation between disability, loneliness, and depression. They conclude that increased social participation and integration are more effective than medication in counteracting depressive disorders among disabled people. In this context it is also important to note that people with mental-health problems are less well integrated in the labour market than physically disabled people (Schafft, 2008).

In contrast, there are several examples that show that participation in the labour market has a positive influence in people's lives. Granerud and Severinson (2006) have found that having colleagues, everyday routines, and participation in the workforce gave people with mental-health problems the feeling of being valuable as active members of society. Borg and Kristiansen (2008) have found that having a job was a key element in the recovery process for people with mental-health problems. Having an ordinary job in an ordinary setting helped the informants to feel normal. The work situation gave them the opportunity to move out of a troubled life and into a world where they had a different status, greater self-esteem, and became part of a community. There are also a number of studies showing that paid work can be an 
important factor for maintaining a drug-free life (Biernacki, 1986). Work fills one's time constructively and enables financial independence (Mclntosh et al., 2008).

\section{Assumptions about why it is difficult to achieve employment}

There can therefore be no doubt that a large proportion of people with mentalhealth problems want to be in employment. Why, then, do they not get jobs? Schafft (2008) provides three explanations for why people with mental-health problems do not find employment. One explanation is that this group has less education and work experience than others. Another explanation may be that many are afraid to apply for jobs because they fear that it will increase their stigmatization and have negative consequences for their recovery processes, welfare benefits, and so forth. A third explanation is that employers are reluctant to take on people with mental disorders because they know too little about what this implies.

Andersen et al. (2012) go a step further and examine in a review article the challenges reported by people with mental disorders after they have started work. They outline several challenges. One is that the employees have difficulties in relating to one's own expectations about exceeding their working time as fast as possible. Social support and the work environment are another challenge. It is difficult to get the workplace to accept and support a gradual return to work. A third area is that the health-care services, NAV, and employers lack a common understanding of problems, solutions, and objectives, and a great amount of the employees feel that there is a competition between the different services - a competition they do not know how to handle. Fourthly, it is difficult to decide when the right time to return to work is. Finally, the employees experience a gap between intentions and implementation; for example, intentions relating to structural adjustments at the workplace take too much time to realize.

We believe that these challenges only to a limited extent apply solely to mental-health problems. People with mental-health problems are a heterogeneous group and there is therefore a great need to consider each individual separately (Møller, 2005). We also assume a difference between a reduced function and a disability. A reduced function refers both to a characteristic of an individual and the society. According to Oliver (1996), the environment, or rather the society, prevents people with impairments from doing what he or she wants to do. The extent to which people with mentalhealth or addiction problems can participate in the labour market is therefore not solely dependent on the disorder, but is the result of the interaction between the individual and how well the workplace is adapted (Briand et al., 2007; Hansen, 2009).

\section{An alternative explanation for why it is difficult to find employment}

We also find the approach that focuses on the interaction between the individual and the environment applied in the commonly used explanation, where sickness absence may be the result of a kind of imbalance between the work requirements as perceived by workers and the possibilities they have to perform the work in accordance with these requirements. There are various models for describing how employees' health is affected by the imbalance 
between the demands and expectations they encounter at work and their possibilities to fulfil them. One of these is the 'job demands-resources model' (Demerouti et al., 2001). This model can be seen as a further development of the 'job demand-control model' (Karasek, 1979) and the 'job demand-controlsupport model' (Karasek \& Theorell, 1990). This demands-resources model includes an extensive description of both demands and resources. The demands may be factors such as physical and mental strain and the organization and management of the company. Resources may be control, autonomy, feedback, social support, and coaching by supervisors (Demerouti et al., 2001; Bakker \& Demerouti, 2007).

The balance between demands and resources can also be seen as part of the broader theoretical orientation that focuses on the person-environment fit (Kristof, 1996; Morley, 2007). One aspect of this focus is precisely the fit between individual and organization and between individual and work. A fit between individual and work is generally a question of finding the person with the best qualifications to perform the defined tasks (Sekiguchi, 2004). But we can imagine the converse of this perspective, where we can ascertain how the workplace can adapt the tasks to the qualifications of the worker.

The basis for these models is thus that problems arise through the imbalance between the job demands and the possibilities to fulfil them. In principle, this imbalance can be offset by two different strategies: the requirements can be reduced or the resources strengthened. If a good balance is achieved between the individual and the work, this will increase job satisfaction and motivation and decrease stress (Sekiguchi, 2004).

For our particular target group, both of these strategies are likely to be relevant. Our basic assumption is that jobs for people with addiction and mental-health problems must be arranged to provide consistency between demands and resources (Hansen, 2010). In practice this means that the work must not place greater demands on the target group than one can reasonably expect them to fulfil. It is also important to be aware of the particular resources of each individual and to adapt the workplace to enable each worker to make use of his or her resources (Saleebey, 1996; Graybeal, 2001). Our main question is therefore: How is it possible to adapt workplaces to people with addiction and mental-health problems?

The simple answer is thus to achieve a balance between demands and resources. Based on our experiences from our study of a project, Pedalen, our answer is yes: it is possible to adapt workplaces to people with addiction and mental-health problems, and we shall illustrate this by presenting some approaches that we argue have helped to facilitate participation in the working life for our target group.

\section{Pedalen: the project}

In 2007, the Norwegian Church City Mission began a project for people with addiction and mental-health problems. Located in Fredrikstad railway station the Mission set up a parking area for bicycles and a bicycle shop. One of the basic ideas, besides establishing a sheltered workplace, was that the project should have an environmental profile and become a positive and visible offer to train travellers and the general population in Fredrikstad. The project was 
named 'Pedalen' (The Pedal) and has since then become an established feature of the townscape.

Pedalen today offers sales of bicycles and equipment, repair and maintenance, and secure bicycle parking. Pedalen has the capacity for ten participants and the core target group is people in aftercare related to drugassisted treatment (Opioid replacement therapy, ORT; Norwegian: Legemiddelassistert rehabilitering, LAR) or in drug-free rehabilitation.

Pedalen is 50 per cent self-financed through the bicycle repair shop and parking. Two managers and a volunteer are responsible for the day-to-day running of the enterprise. One of the managers has thorough expertise in bicycle maintenance and design. Those who get adapted work in Pedalen are described in the data presentation as employees.

\section{Data collection}

A qualitative design has been chosen in this study. Our choice of method was based on an assessment of what data were available and what data could be collected, the cost of various data-collection methods, and what could be achieved with the various types of data (Danermark et al. 2003). The primary goal in this study has been to analyse flexibility as a work-participation strategy for people with addiction and mental-health problems.

The starting point for the design of this study was the desire to conduct an intensive study (Jacobsen, 2005; Danermark et al., 2003) that would focus on gaining the best possible insights into the experience with Pedalen as a work strategy. In our data collection, we chose therefore to concentrate on interviews with employees and other key players in the project. In this way, we mainly captured the positive experiences and to a lesser degree examined reasons why some people did not get the help they needed. This was a conscious choice because our limited resources meant that we had to give priority to the most effective activities.

In all, 12 interviews were conducted. Seven present and former employees of Pedalen were interviewed. Moreover, they were all at different levels or stages of work experience at Pedalen. Some informants had just begun, others had worked at Pedalen for some time, and others had left the project for ordinary work. We also interviewed the two leaders of the Church City Mission who initiated Pedalen as a strategy for work participation. We also interviewed the two daily leaders at Pedalen and the volunteer involved in the project.

Participant observation was also used to observe how the work took place and how the social environment appeared to function. We made our observations at Pedalen during the work hours and also during their daily lunch and their monthly personal meetings. The data from the observations made it possible to analyse interactions among the employees and between the leaders in both social and work contexts and to strengthen the analysis of the interaction and flexibility as a work-participation strategy.

The interviews were mainly conducted at the workplace of the various informants. There were two researchers present at all interviews. Interviews were carried out in a semi-structured format that allowed the researcher to 
investigate key topics regarding flexibility as a work-participation strategy for people with addictions and mental-health problems.

All participants were informed of the objectives of the research and their right to withdraw at any time. The interviews were all digitally audio-recorded, and were subsequently initially analysed directly from the audio files by one of the researchers. The transcriptions were anonymized. The design and implementation of the project was performed under the approval of the Norwegian Social Science Data Services (NSD), the Data Protection Official for Research for all the Norwegian universities and university colleges. The empirical data was transcribed and analysed by all researchers from the printouts.

The analysis consisted of processing the material through meaning condensation, coding, and categorization, using a suitably adapted form (Miles \& Huberman 1994). The analysis of the data we have used in this article is based on a simplified model what Lemire et al. (2012) call the 'Relevance Explanation Finder'. This analytical method is based on the identification of mechanisms, alternative explanations, and influencing factors. In this way the researcher discovers whether the findings can be explained by the theories on which the assumption was based, and whether the assumption that the measure led to the specific changes can be justified. In this case it meant that we were particularly interested in identifying statements that showed how the workplace facilitated the balance between demands and resources for its employees.

Our data analysis revealed two main factors affecting the possibilities of achieving a balance between demands and resources. One was a focus on user-participation and resource-orientation, while the other was a focus on integration and social inclusion.

\section{Presentation of data}

\section{User-participation and resource orientation}

User-participation and resource-orientation seemed to have a strong impact and focus amongst the leaders at Pedalen. The first task when a new employee arrived at Pedalen was to clarify what he or she can do. One of the leaders described how he proceeded:

...I've had a little chat with each of them and I'm always trying to get an idea of their knowledge. What they know how to do and so on... Yes, I really want the lads to work independently... And the whole time we adapt the system so that they can work independently...

The focus of this conversation was what the employees can do, not what the employer wanted them to do. It was also interesting to note that this leader stressed that it was the system that must be adapted for the employees to function as desired. Nevertheless, regular supervision by the staff was needed - both to provide advice and guidance and occasionally to set clear limits of acceptable behaviour. The leaders were aware that any matters that needed to be addressed should be discussed in a way that would be as least 
troublesome for the employee concerned. And this was described by one of the leaders as follows:

If there's a personal matter, we discuss it personally with the individual. We don't get annoyed with anyone. We give advice and say, 'Maybe we could do things differently'. We don't tell people off here...

It was clear that the employees felt that the focus was on what they are capable of and that the employer appreciates the skills they mastered. This was illustrated by the following description by one of the employees:

...I like it here. I remember I was down here and had a look and I thought I hope I'll get a job at Pedalen soon. And I got the job! It's great here. XX said, 'You know about all that technical stuff'. I can fix things inside lamps. It's called the pole; the shiny metals are called the pole. If they're not there, you'll never get power in the bulb. $Y Y$ and $X X$ tried but they couldn't do it. I said I'll try and then I couldn't do it. Then I thought if I put the screwdriver on the pole and bend it out a bit, then I put the wires in place and the soldering on the bulb, then screw in the bulb and roll the wheel, then it'll light up. I'm really pleased I got this job....

The leaders were well aware that if people are to function properly in a workplace, more is needed than just skills. The employees must also be part of a social environment. One of the leaders emphasized this with the words: 'The most important thing is the environment'. He clarified this further with the following statement:

\begin{abstract}
Social coping is important, like feeling one can manage everything from having lunch to being part of a social group, feeling that it's good to be here. So your self-confidence gets a boost. Many of them are afraid to have lunch. So it's about overcoming minor obstacles like that. In some cases, the workers have told us that they're here to learn, not to eat. So sometimes they feel the threshold is too low. But it's all about finding the right balance. And the focus is that we're here to do a job. And this has been a challenge for providing good training - to make sure we get people in activity. It's vital to create a good workplace, so they don't experience new failures...
\end{abstract}

\title{
Integration and social inclusion
}

Pedalen contributed also as a social workplace both for the leaders and the employees. The leaders attached great importance to social activities and organized trips for employees, such as annual visits to bicycle manufacturers and also other companies connected to the bicycle business. These trips were of great importance for conversations over lunch - which was a common meeting point for both employees and leaders - and also an inspiration for enhancing the work with bicycles. These social activities brought everyone in Pedalen together in conversations about common experiences and common goals for the future. For most employees, these social activities were an opportunity to socialize with others outside working hours.

The social environment was also important to the employees and one of them described how the work has given him a friend whom he also meet in his spare time: 
...l've made a friend here. We live quite near each other. So for some months now we've been getting together at his place or mine. We watch films and play Playstation - make something to eat and so on. We have a nice time together. That's good. It's good to have friends.

Although Pedalen is a sheltered workplace, it is emphasized that certain demands should be placed on the employees. Also with regard to the social tone among the employees, it is stressed that it should be like ordinary workplace, and discussions about alcohols, drugs, illness or medication was viewed as private and unsuitable as topics of conversation. One of the leaders explained:

...When you're at work, you're at work and we try to make things function like any other job. You don't open up and talk about your big drug problem. It's not a good idea to start with that if the everyday things are going ok otherwise. Other people take medicine for other things without it being some kind of big issue. They get medicines for their problems...

Although Pedalen involves a shielding from certain types of demands the employees may encounter elsewhere in society, it is in many ways one of the least sheltered workplaces in Fredrikstad. With its central location at the railway station, Pedalen is a distinct element in the urban landscape. It is also obvious that Pedalen is dependent on giving customers good service. Although it is the only business that offers secure bicycle parking at the railway station, they compete with others in bicycle repairs. This was something the employees realized very clearly, as this statement shows:

... it's worthwhile work. In a way, it's a normal shop. Except the people working here, are unskilled. But we still aim for quality. You can see that in all the bikes we get. And people are satisfied. So that shows people are pleased with the work that's being done...

The employees also found it important that the job made them part of normal working life. One of them put it this way:

...Yes, you've got to feel you're part of society. You're doing something useful. And you come home and well, yes, you've done something. Kind of like, well, now it's the weekend. You look forward to the weekend...

The workers' descriptions of their everyday work in such statements were quite similar to descriptions of ordinary businesses that are dependent on customers and seasonal fluctuations and have to deal with tasks that pile up.

\section{Discussion}

Arrangements to help people with addiction and mental-health problems into employment are based on two different strategies. Prevocational training creates sheltered work arrangements where employees can receive education and training to enable them eventually to qualify for jobs in the mainstream labour market, while supported employment provides jobs in ordinary workplaces where employees with special needs receive comprehensive support to enable them to fulfil the requirements for the job (Crowther et al., 
2001). Both strategies are ways of building the employees' resources so that they can fulfil the workplace's ordinary demands.

\section{Individual resources}

A basic principle of this project thus seems to be to take the employees seriously and to help each individual to utilize and develop his inherent resources. The focus is not on diagnoses and problems, but rather on the kind of skills and resources each employee represents. The basis here is clearly the principles of social work known as strengths-based social work (Saleebey, 1996; Graybeal, 2001). We regard Pedalen as a workplace where the work adapts to the worker and not the converse. In our understanding of the data, Pedalen is flexible in two ways. First, it adapts the work requirements in order to avoid placing excessive demands on the individual employee. The work requirements are not adapted to the employer's need to boost production or other key expectations found in ordinary working life. Secondly, the leaders make an effort to find each employee's particular resources. They become aware of what each individual can do and try to adapt demands and resources so that each person can utilize his resources and perform the tasks assigned to him. The leaders also emphasize following up the employees with assistance and instructions so that they can broaden their responsibilities, thus strengthening their resources.

\section{Social inclusion}

At the same time, the leaders are well aware that this group of employees has certain challenges, such as those related to social participation. These challenges are not ignored, but an attempt is made to help the individual employee to master the situations he encounters. Pedalen differs from many sheltered workplaces where the leaders and the employees do not socialize during lunch-breaks. But at Pedalen it is important that everybody feel included. Therefore the leaders have an open-door policy and try to mingle with the employees as much as possible, also during breaks. Like Solheim (2007) we see this form of social inclusion as a way of building a network and augmenting social capital. As Putnam (1995) points out, social capital is an important part of people's resources.

Another important aspect of Pedalen is the way the work provides the employees with status and self-esteem. On the one hand, Pedalen makes an effort to become an ordinary company that conducts normal business activities; on the other hand, it is a sheltered enterprise where all employees have a need for adapted work. In the case of Pedalen, it provides adapted and sheltered jobs, but it is also a customer-oriented enterprise. In practice this means that the employees feel that although they have adapted work, they are integrated into ordinary working life. It can easily be imagined that working in a sheltered enterprise could stigmatize the employees. Although Pedalen involves a shielding from certain types of demands, its employees can meet elsewhere. It is in many ways one of the least sheltered workplaces in the town. Centrally located at the railway station, Pedalen is a distinct element in the townscape; one could imagine that this might lead to stigmatization of the workers. But they have clearly not experienced this. 
One challenge in measures such as supported employment is that the organizational culture of the company may not be sufficiently inclusive. Kirsh (2000) shows that people with mental-health problems place a great amount of emphasis on the work environment being supportive, fair, tolerant, and socially inclusive. These qualities are encountered at Pedalen, which thus represents an organizational culture that makes employees feel included, increasing the chances that they can master the challenges they face.

The employees identify with the ideology of the enterprise. One important aspect of Pedalen is that it appears to people as a useful initiative that benefits society. Several of the informants point out how important it is that the employees receive wages and pay taxes. We also see that encouraging more cycling in society is viewed as a politically correct activity. It is quite evident that the Pedalen employees feel that their work is making a positive contribution to society. Here the main aspect is that Pedalen makes it easier for train travellers to cycle to and from the station, and is therefore an ecofriendly initiative. In addition, several informants emphasized that Pedalen's activities on the premises have made the building itself and its interior more attractive and the building has thus enhanced the general upgrading of the environment outside the railway station. This achieves what is called an 'ideological congruence '(Morley, 2007), which helps the employees to feel that their work is meaningful.

\section{Flexibility}

What then actually enables Pedalen to provide for its employees as described here? We believe that the answer lies in the concept of flexibility. With regard to work in general, flexibility is a term used in different contexts and it is difficult to find a precise definition (Skorstad, 2009). But the concept is almost always positive. Flexibility is often linked to a strategy to meet the challenges facing an industry in regard to international competition, technological developments, and rapid changes in market conditions (Karlsson, 2009). Flexibility can be linked to various aspects of work, such as flexible employment, flexible companies, flexible workers, and so on. Very often flexibility is mentioned in such contexts in absolute terms: one is either flexible or inflexible. In what respect a person is flexible carries less weight. Wilton (2004) shows, for example, that the trends which are usually described as increased flexibility in work generally make it more difficult rather than easier for disabled people to function at work. Wilton's conclusions are admittedly based on a study from Canada, but there is no reason to believe that the work context differs greatly between Canada and Norway in this respect.

Karlsson (2009) asks the question 'Good and bad flexibility - for whom?' His review of the relevant literature shows, not surprisingly, that the answer to this question depends on how one defines flexibility and on what interests form the basis for one's assessment of what is good or bad. A clear example of this is the distinction between being flexible - where the worker is required to react appropriately in order to adapt to changing conditions at work - and having flexibility - where the worker has the possibility of exercising some degree of autonomy. When the employee is expected to vary his work by performing different kinds of tasks, one makes use of so-called functional flexibility (Atkinson, 1984). Such variation in work is normally considered to be positive for the employee, but it is important to bear in mind that it is not the employee's wish for variety that determines the work he has to perform, but 
rather the needs of the employer. In practice it therefore makes a considerable difference to a worker whether he or she is flexible or possesses flexibility (Bekkengen, 2002). Yet both situations are described as examples of flexible working. At Pedalen we see an example of a workplace where the workers have flexibility, that is, the latitude to decide for themselves how they work, and our conclusion is that this kind of flexibility is essential if one wishes to create workplaces for people with addiction and mental-health problems.

\section{Summary}

The success factor for getting people with addictions and mental-health problems into employment is to find a balance between the demands placed on an employee and the resources of the employee. The leaders of Pedalen seem to manage this by having a focus on each individual's resources. The leaders assess the person's resources and monitor his progress; in this way they can find out what he is able manage and can adapt his work accordingly. Next they try to strengthen these resources. An important part of this strategy is to create an environment of social inclusion and to strengthen their status and self-esteem. Then they adapt the work demands to each individual's resources. To achieve this, the enterprise must be flexible - in the sense that the employees have flexibility and the work is adapted to them, not vice versa. In this way it is possible to adapt workplaces to people with addiction and mental-health problems.

\section{References}

Andersen, M. F., Nielsen, K. M., \& Brinkmann, S. (2012). Meta-synthesis of qualitative research on return to work among employees with common mental disorders. Scandinavian journal of work, environment \& health, 38(2), 93-104. doi: 10.5271/sjweh.3257

Bakker A. B. \& Demerouti E. (2007). The Job Demands-Resources model: state of the art. Journal of Managerial Psychology, 22(3), 309-328.

Bekkengen L (2002). Man får välja - Om föräldraskap och föräldraledighet $i$ arbetsliv och familjeliv [You have to choose - Parenting and parental leave in work and family]. Malmø: Liber forlag.

Biernacki, P. (1986). Pathways from heroin addiction: Recovery without treatment. Philadelphia: Temple University Press.

Briand, C., Durand, M.-J., St-Arnaud, L., \& Corbière, M. (2007). Work and mental health: learning from return-to-work rehabilitation programs designed for workers with musculoskeletal disorders. International journal of law and psychiatry, 30(4), 444-457.

Crowther, R. E., Marshall, M., Bond, G. R., \& Huxley, P. (2001). Helping people with severe mental illness to obtain work: systematic review. British Medical Journal, 322(7280), 204-208.

Danermark, B., Ekström M., Jacobsen, L. \& Karlsson, J. C. (2003). Att förklara samhället [Explaining society], Lund: Studentlitteratur.

Dekkers-Sánchez, P. M., Hoving, J. L., Sluiter, J. K., \& Frings-Dresen, M. H. (2008). Factors associated with long-term sick leave in sick-listed employees: a systematic review. Occupational and environmental medicine, 65(3), 153-157. 
Demerouti, E., Bakker, A. B., Nachreiner, F., \& Schaufeli, W. B. (2001a). The job demands-resources model of burnout. Journal of Applied Psychology, 86(3), 499-512.

Elstad, J. I., \& Vabø, M. (2008). Job stress, sickness absence and sickness presenteeism in Nordic elderly care. Scandinavian Journal of Public Health, 36(5), 467-474.

Evans, J., \& Repper, J. (2000). Employment, social inclusion and mental health. Journal of psychiatric and mental health nursing, 7(1), 15-24.

Granerud, A., \& Severinsson, E. (2006). The struggle for social integration in the community-the experiences of people with mental health problems. Journal of Psychiatric and Mental Health Nursing, 13(3), 288-293.

Graybeal, C. (2001). Strengths-based social work assessment: Transforming the dominant paradigm. Families in Society: The Journal of Contemporary Social Services, 82(3), 233-242.

Hammer, T. \& Øverbye, E. (Eds.) (2006). Inkluderende arbeidsliv? Erfaringer og strategier [Inclusive work? Experiences and strategies]. Oslo: Gyldendal Akademisk.

Hansen, G. V. \& Dybvik, K. A. (2009). Betydningen av arbeid for funksjonshemmedes tilfredshet med deres dagligliv $\mathrm{i}$ forhold til andre livskvalitetsområder [The importance of work for everyday life-satisfaction for disabled people, compared with other aspects of quality of life]. The SOR Report 2, 8-26

Hansen, G. V. (2009). Et fleksibelt blikk på avtalen om inkluderende arbeidsliv [A flexible view of the agreement on inclusive work]. In J. C. Karlsson \& $T$. Claussen, (Eds.) Den sköra balansen: arbetslivet och flexibilitetens tvetydigheter [The delicate balance: working life and the ambiguities of flexibility] (pp. 133-145). Växjö: Växjö University

Hansen, G. V. (2007). Samarbeid uten fellesskap - om individuelle planer i kommunalt psykisk helsearbeid [Cooperation without a community - individual plans in local government mental health care]. Karlstad University Studies 2007:15.

Jacobsen, D. I. (2005). Hvordan gjennomføre undersøkelser? Innføring i samfunnsvitenskapelig metode [How to conduct surveys? An introduction to social science methodology]. Oslo, Høyskoleforlaget.

Karasek, R. \& Theorell, T. (1990). Healthy work: stress, productivity, and the reconstruction of working life. New York: Basic Books.

Karasek Jr, R. A. (1979). Job demands, job decision latitude, and mental strain: Implications for job redesign. Administrative science quarterly, 24(2), 285-308.

Karlsson, J. C. (2009). Den dubbeltydiga flexibiliteten [Ambiguous flexibility]. In J. C. Karlsson \& T. Claussen (Eds.): Den sköra balansen: arbetslivet och flexibilitetens tvetydigheter [The delicate balance: working life and the ambiguities of flexibility] (pp. 43-56). Växjö: Växjö University.

Kristof, A. L. (1996). Person-organization fit: An integrative review of its conceptualizations, measurement, and implications. Personnel psychology, 49(1), 1-49.

Kvale, S. (2001). Det kvalitative forskningsintervju [The qualitative research interview]. Oslo: Gyldendal Akademisk. 
Lemire, S. T., Nielsen, S. B., \& Dybdal, L. (2012). Making contribution analysis work: A practical framework for handling influencing factors and alternative explanations. Evaluation, 18(3), 294-309. doi: 10.1177/1356389012450654

McIntosh, J. Bloor, M. \& McKegany N. (2008). Drug treatment and the achievement of paid employment. Addiction Research and Theory, 16(1), 37-45. doi: $10.1080 / 16066350701699197$

Morley, M. J. (2007). Person-organization fit. Journal of Managerial Psychology, 22(2), 109-117.

Mykletun A \& Knudsen A K. (2009). Tapte arbeidsår ved uførepensjonering for psykiske lidelser. En analyse basert på FD-trygd [Lost working years due to disability retirement. An analysis based on the FD-trygd database]. Oslo, Institute for Public Health.

National Strategic Plan for Work and Mental Health, 2007-2012. Oslo: Ministry of Labour and Ministry of Health and Care services.

OECD (2010). Sickness, Disability and Work, Breaking the Barriers, a synthesis of findings across OECD countries. Paris: Organisation for Economic Co-operation and Development.

Oliver, M. (1996). Defining impairment and disability: issues at stake. In C. Barnes \& G. Mercer (Eds.) Exploring the divide: IIIness and disability (pp. 39-54). Leeds, UK: The Disability Press.

Ose, S. O., Kaspersen, S. L., Jensberg, H., Kalseth, B. \& Lilleeng, S. (2009). Psykisk helse og arbeidsliv - behov for nye tilnærminger [Mental health and employment - the need for new approaches]. In Søkelys på arbeidslivet [Spotlight on working life] 1/2009, 26, 75-92.

Plan for Work and Mental Health 2013-2016. Oslo: Ministry of Labour and Ministry of Health Care services.

Putnam, R. D. (1995). Tuning in, tuning out: The strange disappearance of social capital in America. PS: Political science \& politics, 28(04), 664-683.

Reneflot, A., \& Evensen, M. (2011). Arbeidsledighet og psykisk helse blant unge $i$ Norden: en kunnskapsoversikt [Unemployment and mental health among young people in the Nordic countries: an overview of knowledge] Gothenburg: Nordic School of Public Health (NHV).

Saleebey, D. (1996). The strengths perspective in social work practice: Extensions and cautions. Social work, 41(3), 296-305.

Schafft, A. (2008). Psykiske lidelser og arbeidsintegrering i Skandinavia: En kunnskapsstatus [Mental disorders and work integration in Scandinavia. The status of knowledge]. Oslo: The Work Research Institute, Report, 4.

Sekiguchi, T. (2004). Person-organization fit and person-job fit in employee selection: A review of the literature. Osaka Keidai Ronshu, 54(6), 179-196.

Skorstad E (2009). Den tvetydige fleksibiliteten [Ambiguous flexibility]. In J. C. Karlsson \& T. Claussen (Eds.) (2009): Den sköra balansen: arbetslivet och flexibilitetens tvetydigheter [The delicate balance: working life and the ambiguities of flexibility] pp. 12-42. Växjö: Växjö University.

Solheim, L. J. (2007). Savis - ein modell for sosial inklusjon [Savis: a model for social inclusion]. In O. P. Askheim \& B. Starrin (Eds.) Empowerment i teori og praksis [Empowerment in theory and practice] (pp. 97 - 111). Oslo: Gyldendal Akademisk. 
Sundell, T. (2013). Utvikling i sykefraværet 4. kvartal 2012 [Trends in sickness absence, 4th quarter 2012]. Oslo: Arbeids og Velferdsdirektoratet, seksjon for statistikk (Statistics Department, Directorate of Labour and Welfare).

Thorsen, K. \& Clausen, S. (2008). Funksjonshemning, ensomhet og depresjon: Hva betyr ensomhet for om personer med funksjonshemning opplever depresjon? [Disability, loneliness and depression. What is the significance of loneliness in disabled people's experiences of depression?] Tidsskrift for Norsk Psykologforening, 45(1) 19-27.

Van Dongen, C. J. (1996). Quality of life and self-esteem in working and nonworking persons with mental illness. Community Mental Health Journal, 32(6), 535-548.

Wilton, R. D. (2004). From flexibility to accommodation? Disabled people and the reinvention of paid work. Transactions of the Institute of British Geographers, 29(4), 420-432. 